\title{
Urologic (Excluding Kidney)
}

National Cancer Institute

\section{Source}

National Cancer Institute. Urologic (Excluding Kidney). NCI Thesaurus. Code C19194.

A funding category. 